\title{
North American isoprene influence on intercontinental ozone pollution
}

\author{
A. M. Fiore ${ }^{1}$, H. Levy II $^{2}$, and D. A. Jaffe ${ }^{2}$ \\ ${ }^{1}$ NOAA Geophysical Fluid Dynamics Laboratory, Princeton, New Jersey, USA \\ ${ }^{2}$ Department of Science and Technology, University of Washington-Bothell, Washington, USA \\ Received: 11 October 2010 - Published in Atmos. Chem. Phys. Discuss.: 25 October 2010 \\ Revised: 4 February 2011 - Accepted: 4 February 2011 - Published: 22 February 2011
}

\begin{abstract}
Changing land-use and climate may alter emissions of biogenic isoprene, a key ozone $\left(\mathrm{O}_{3}\right)$ precursor. Isoprene is also a precursor to peroxy acetyl nitrate (PAN) and thus affects partitioning among oxidized nitrogen $\left(\mathrm{NO}_{\mathrm{y}}\right)$ species, shifting the balance towards PAN, which more efficiently contributes to long-range transport relative to nitric acid $\left(\mathrm{HNO}_{3}\right)$ which rapidly deposits. With a suite of sensitivity simulations in the MOZART-2 global tropospheric chemistry model, we gauge the relative importance of the intercontinental influence of a $20 \%$ increase in North American (NA) isoprene and a $20 \%$ decrease in NA anthropogenic emissions (nitrogen oxides $\left(\mathrm{NO}_{\mathrm{x}}\right)$, non-methane volatile organic compounds (NMVOC) and $\mathrm{NO}_{\mathrm{x}}+\mathrm{NMVOC}+$ carbon monoxide + aerosols). The surface $\mathrm{O}_{3}$ response to NA isoprene emissions ( $\triangle \mathrm{O}_{3}$ ISOP) in surface air over NA is about one third of the response to all NA anthropogenic emissions $\left(\triangle \mathrm{O}_{3}\right.$ ANTH; although with different signs). Over intercontinental distances, $\Delta \mathrm{O}_{3}$ ISOP is relatively larger; in summer and fall, $\Delta \mathrm{O}_{3}$ ISOP in surface air over Europe and North Africa (EU region) is more than half of $\Delta \mathrm{O}_{3}$ ANTH. Future increases in NA isoprene emissions could thus offset decreases in EU surface $\mathrm{O}_{3}$ resulting from controls on NA anthropogenic emissions. Over the EU region, $\triangle$ PAN_ISOP at $700 \mathrm{hPa}$ is roughly the same magnitude as $\triangle$ PAN_ANTH (oppositely signed). Outside of the continental source region, the percentage changes in PAN are at least twice as large as for surface $\mathrm{O}_{3}$, implying that long-term PAN measurements at high altitude sites may help to detect $\mathrm{O}_{3}$ precursor emission changes. We find that neither the baseline level of isoprene emissions nor the fate of isoprene nitrates contributes to the large diversity in model estimates of the anthropogenic
\end{abstract}

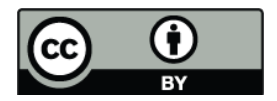

Correspondence to: A. M. Fiore (arlene.fiore@noaa.gov) emission influence on intercontinental surface $\mathrm{O}_{3}$ or oxidized nitrogen deposition reported in the recent TF HTAP multimodel studies (TFHTAP, 2007).

\section{Introduction}

A recent internationally coordinated effort has estimated hemispheric pollutant transport at northern mid-latitudes and assessed uncertainties in these estimates (TFHTAP, 2007). Intended to inform future policy negotiations under the Convention on Long-Range Transboundary Air Pollution (CLRTAP), work to date has largely focused on "source-receptor" (SR) relationships (i.e., the pollutant response in a receptor region to an emissions perturbation within a source region) for anthropogenic emissions (TFHTAP, 2007; Sanderson et al., 2008; Shindell et al., 2008; Fiore et al., 2009; Reidmiller et al., 2009; Jonson et al., 2010; Anenberg et al., 2009). In regions heavily vegetated with isoprene-emitting plants, however, anthropogenic emissions of nitrogen oxides $\left(\mathrm{NO}_{\mathrm{x}}\right)$ interact with isoprene, a highly reactive nonmethane volatile organic compound (NMVOC), to produce ozone $\left(\mathrm{O}_{3}\right)$ and thereby contribute to urban and regional air pollution (e.g.,Trainer et al., 1987; Chameides et al., 1988). Below, we describe our application of a three-dimensional global chemical transport model (CTM) to examine the sensitivity of intercontinental $\mathrm{O}_{3}$ pollution to changes in NA isoprene emissions and chemistry alongside changes in NA anthropogenic emissions.

Isoprene emissions increase strongly with temperature and sunlight and at northern mid-latitudes occur from spring through fall with a summer peak (e.g., Guenther et al., 2006). Global isoprene emissions are estimated to be at least five times higher than all anthropogenic NMVOC emissions and

Published by Copernicus Publications on behalf of the European Geosciences Union. 
have been shown to enhance the tropospheric $\mathrm{O}_{3}$ burden (e.g., Fuentes et al., 2000; Folberth et al., 2006; Guenther et al., 2006; Wild, 2007; Wu et al., 2007; Pfister et al., 2008). In the eastern United States, July isoprene emissions have been estimated to be 4 to over 10 times higher than anthropogenic NMVOC (e.g., Fiore et al., 2005). Isoprene, oxidized in the presence of the anthropogenic $\mathrm{NO}_{\mathrm{x}}$ available in this region, contributes as much as $15-25 \%$ to surface $\mathrm{O}_{3}$ in summer as compared to $\sim 2 \%$ from anthropogenic NMVOC (Horowitz et al., 1998) and may play a key role in hemispheric transport of $\mathrm{O}_{3}$.

In addition to $\mathrm{O}_{3}$, various organic nitrates, including peroxy acetyl nitrate (PAN) which is particularly relevant for intercontinental transport, are produced during photochemical reactions involving isoprene (and to a lesser extent, other NMVOCs) and $\mathrm{NO}_{\mathrm{x}}$. Formation of PAN alters the balance between deposition and export of oxidized nitrogen ( $\mathrm{NOy}=$ $\mathrm{NO}_{\mathrm{x}}+\mathrm{HNO}_{3}+\mathrm{PAN}+$ other minor oxidation products) from the NA region (e.g., Roberts et al., 1995; Horowitz et al., 1998). Frontal passages and convection, which ventilate the eastern NA boundary layer, can loft PAN to higher, colder altitudes where it is thermally stable and can undergo longrange transport and contribute to $\mathrm{O}_{3}$ production upon decomposition in air masses that warm as they subside (e.g., Moxim et al., 1996; Liang et al., 1998; Val Martin et al., 2008; Fang et al., 2010; Fischer et al., 2010). Two pathways contribute approximately equally to intercontinental transport of $\mathrm{O}_{3}$ pollution: (1) production of $\mathrm{O}_{3}$ over the source region which is then exported, (2) export of precursors, PAN in particular, which then produce $\mathrm{O}_{3}$ during transit to the downwind region (Liang et al., 1998; Jacob et al., 1999; Wild et al., 2004; West et al., 2009; Lin et al., 2010). PAN may also be a useful proxy for changes in $\mathrm{O}_{3}$ precursor emissions, which may be detected more readily in observations of PAN than $\mathrm{O}_{3}$ (Jaffe et al., 2007; Fischer et al., 2011).

Large uncertainties envelop the current understanding of the magnitude and distribution of isoprene emissions and subsequent oxidation chemistry (e.g., Steiner and Goldstein, 2007; Arneth et al., 2008; Carlton et al., 2009; Lelieveld et al., 2008). This uncertainty propagates into PAN formation and therefore the impact of isoprene- $\mathrm{NO}_{\mathrm{x}}-\mathrm{O}_{3}$ chemistry on foreign regions (Kuhn et al., 1998; Emmerson and Evans, 2009). Of particular relevance for $\mathrm{O}_{3}$ produced in the source regions is the uncertain interaction of isoprene with the $\mathrm{NO}_{\mathrm{x}}$ budget via isoprene nitrate formation; the ultimate influence of isoprene on $\mathrm{O}_{3}$ may hinge on the poorly understood fate of isoprene nitrates (e.g., von Kuhlmann et al., 2004; Ito et al., 2009; Perring et al., 2009; Paulot et al., 2009; Weaver et al., 2009). While we expect these uncertainties to contribute to model diversity in "baseline" simulations for the present atmosphere, it is unclear whether they are also contributing to the range in model estimates of the responses of surface $\mathrm{O}_{3}$ and $\mathrm{NO}_{\mathrm{y}}$ deposition to anthropogenic emission perturbations, as reported in prior TF HTAP publications (Sanderson et al., 2008; Fiore et al., 2009; Reidmiller et al., 2009).
Although anthropogenic emissions of isoprene may be a major contributor to ambient isoprene in some urban settings, the biogenic source overwhelmingly dominates over much of the northern mid-latitudes during the warm season (Reimann et al., 2000; Guenther et al., 2006; Dollard et al., 2007). Even the biogenic isoprene source, however, is heavily influenced by human activities via land-use changes, as has occurred historically with changes in cropland areas (e.g., Lathière et al., 2010). Future decisions to establish poplar (a high isoprene-emitting species) plantations for biofuel or to convert vast forested regions to croplands (low isoprene emitters) could dramatically alter future isoprene emissions and thereby air quality (e.g., Wiedinmyer et al., 2006; Avise et al., 2009; Chen et al., 2009). The strong temperature dependence of isoprene emissions suggests that they will increase in a warmer climate, but other factors (higher carbon dioxide, drought, pollutant exposure, insect herbivory) could offset this increase (e.g., Pacifico et al., 2009; Rosenstiel et al., 2003; Guenther et al., 2006). The relative importance of future changes in climate and land-use on isoprene emissions is unclear, but the potential for humans to alter isoprene emissions deserves consideration.

As a first step towards understanding the role of isoprene emissions in intercontinental $\mathrm{O}_{3}$ pollution, we use the MOZART-2 global CTM (Sect. 2) to quantify the influence of NA isoprene on $\mathrm{O}_{3}$ and PAN in surface air and at $700 \mathrm{hPa}$, as well as $\mathrm{NO}_{\mathrm{y}}$, deposition at northern mid-latitudes in $\mathrm{Au}-$ gust (Sect. 3) and throughout the year (Sect. 4). We also explore the potential for PAN measurements to detect $\mathrm{O}_{3}$ precursor emission changes (Sect. 5). We then evaluate the impact of uncertainties in isoprene emissions and chemistry on estimates of hemispheric responses to NA anthropogenic emission controls (Sect. 6) and discuss the implications of our findings (Sect. 7).

\section{Model simulations}

We use the MOZART-2 model (Horowitz et al., 2003) in the same configuration ("MOZARTGFDL-v2") as applied to the year 2001 for the multi-model studies coordinated by the Task Force on Hemispheric Transport of Air Pollution (TFHTAP; www.htap.org) (e.g., TFHTAP, 2007). Briefly, the model meteorology is driven by the NCEP reanalysis (Kalnay et al., 1996) for the year 2001 with a horizontal resolution of $1.9^{\circ} \times 1.9^{\circ}$ with 28 vertical levels. Emissions are as in Horowitz et al. (2003) except for biomass burning for which we use GFED version 2 (van der Werf et al., 2006) for the year 2001. Isoprene emissions are a monthly varying climatological inventory (Guenther et al., 1995; Horowitz et al., 2003). We modified the isoprene oxidation chemistry from that of Horowitz et al. (2003) to use a $4 \%$ yield of isoprene nitrates and $40 \%$ rate of recycling back to $\mathrm{NO}_{\mathrm{x}}$ upon oxidation of these nitrates; these values are consistent with observed alkyl and peroxy nitrates over the eastern United States in 

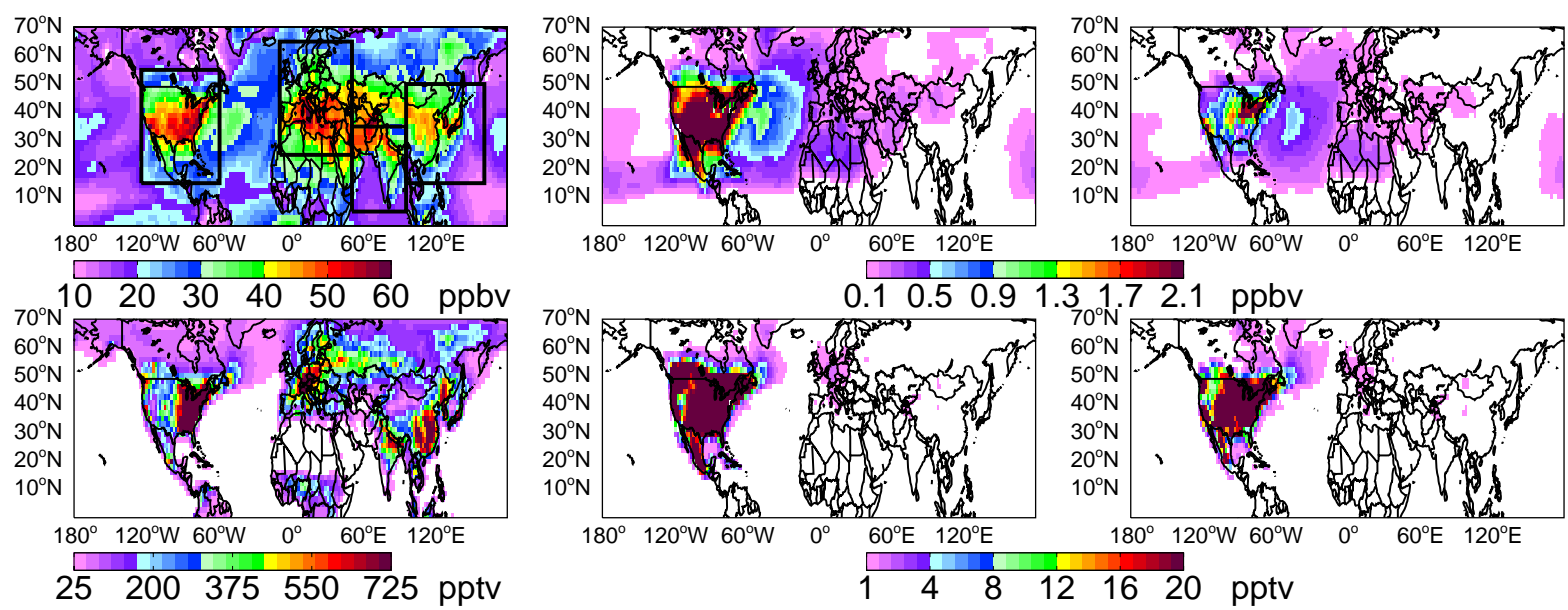

Fig. 1. August 2001 surface mixing ratio of $\mathrm{O}_{3}$ (top) and PAN (bottom) in the MOZART-2 base (SR1) simulation (left); $\Delta \mathrm{O}_{3}-\mathrm{ANTH}$ (top) and $\triangle$ PAN_ANTH (bottom) diagnosed as the difference between the SR1 and SR6NA simulations (middle); and $\Delta \mathrm{O}_{3}$ ISOP (top) and $\triangle$ PAN_ISOP (bottom) diagnosed as the difference between the ISOPNA and SR1 simulations (right). Regions outlined in black, from left to right are: North America (NA), Europe and North Africa (EU), South Asia (SA), and East Asia (EA), as in TFHTAP (2007). Note the different scales on each color bar. Areas below the minimum values are shown in white.

summer (Horowitz et al., 2007). (Note that we do not explicitly track secondary multi-functional organic nitrates which serve as a terminal sink in Horowitz et al. (2007) but we do increase the hydroxycarbonyl yield to match that of $\mathrm{NO}_{\mathrm{x}}$.) The SYNOZ parameterization provides the stratospheric $\mathrm{O}_{3}$ upper boundary condition (McLinden et al., 2000), implemented as described by Emmons et al. (2010). All simulations are spun up for seven months prior to the analysis year of 2001.

In the TF HTAP "source-receptor (SR)" simulations, anthropogenic emissions of $\mathrm{O}_{3}$ precursors were decreased by $20 \%$, separately for $\mathrm{NO}_{\mathrm{x}}, \mathrm{NMVOC}$, and carbon monoxide (CO), and for all three precursors together (plus aerosols), within each of the four major northern mid-latitude source regions in Fig. 1. We focus here on the NA source region, employing four MOZART-2 SR simulations (Table 1): base (denoted SR1) and perturbation simulations with $20 \%$ decreases in NA emissions, for anthropogenic $\mathrm{NO}_{\mathrm{x}}$ (SR3NA), anthropogenic NMVOC (SR4NA), and all anthropogenic $\mathrm{O}_{3}$ precursors plus aerosols combined (SR6NA). The differences between these perturbation simulations and SR1 provide an estimate of the response to changes in anthropogenic emissions. Hereafter, we refer to the decreases in $\mathrm{O}_{3}$ and PAN produced by the anthropogenic emission reductions as $\triangle \mathrm{O}_{3} \_$ANTH and $\triangle$ PAN_ANTH, respectively.

Of the four continental source regions in Fig. 1, North America is the most abundant isoprene emitter in MOZART-2, with $35 \mathrm{Tg} \mathrm{Ca}^{-1}$ as compared to 22,12 , and $17 \mathrm{Tg} \mathrm{Ca}^{-1}$ from East Asia, Europe, and South Asia, respectively. Qualitatively, this ranking is consistent with that for the multi-model average regional emissions of non-anthropogenic NMVOC from the models participat- ing in the TF HTAP studies (determined as the differences between values reported in Tables A2 and A3 of Fiore et al., 2009). Anthropogenic emissions of $\mathrm{NO}_{\mathrm{x}}$, $\mathrm{CO}$ and NMVOC from the NA region in MOZART-2 are $0.88 \times 10^{1} \mathrm{Tg} \mathrm{N} \mathrm{a}{ }^{-1}, 1.00 \times 10^{2} \mathrm{Tg} \mathrm{a}^{-1}$, and 0.66 $\times 10^{1} \mathrm{TgC} \mathrm{C}^{-1}$, respectively. The corresponding $\mathrm{TF}$ HTAP values (mean \pm standard deviation across models) are $0.74 \times 10^{1} \pm 0.04 \times 10^{1} \mathrm{Tg} \mathrm{Na}^{-1}, 1.01 \times 10^{2} \pm 0.19$ $\times 10^{2} \mathrm{Tg} \mathrm{a}^{-1}$ and $0.16 \times 10^{2} \pm 0.071 \times 10^{2} \mathrm{Tg} \mathrm{Ca}^{-1}$ for NA anthropogenic emissions of $\mathrm{NO}_{\mathrm{x}}, \mathrm{CO}$ and NMVOC, respectively (Table A3 of Fiore et al., 2009). The lower anthropogenic NMVOC emissions and higher anthropogenic $\mathrm{NO}_{\mathrm{x}}$ in MOZART-2 imply that $\mathrm{O}_{3}$ and PAN formation may be more sensitive to NA isoprene vs. anthropogenic NMVOC emissions compared to other CTMs. Given that (1) the NA isoprene emissions are still more than double the TF HTAP value for anthropogenic NMVOC emissions, (2) isoprene reactivity is generally several times higher than that for anthropogenic NMVOC (e.g., Fuentes et al., 2000), and (3) surface $\mathrm{O}_{3}$ over NA is more sensitive to $\mathrm{NA} \mathrm{NO}_{x}$ than anthropogenic NMVOC from spring through fall in the models participating in the TF HTAP multi-model studies (Fiore et al., 2009; their Fig. 4), we expect our results to be robust to uncertainties in anthropogenic NMVOC emissions. The decline in eastern US anthropogenic $\mathrm{NO}_{\mathrm{x}}$ emissions over recent years, which occurred after 2001, will tend to decrease the sensitivity of $\mathrm{O}_{3}$ formation to isoprene, suggesting that the current $\mathrm{O}_{3}$ sensitivity to NA isoprene emissions may be smaller than that estimated below.

The MOZART-2 SR1 simulation, which has previously been evaluated with observations of surface $\mathrm{O}_{3}$ and $\mathrm{O}_{3}$ profiles as part of the TF HTAP effort (Fiore et al., 2009; 
Table 1. MOZART-2 Simulations.

\begin{tabular}{|c|c|}
\hline Name & Description \\
\hline SR1 & Base case (see Sect. 2 for details) \\
\hline SR3NA & SR 1 but with anthropogenic $\mathrm{NO}_{\mathrm{x}}$ emissions within NA decreased by $20 \%$ \\
\hline SR4NA & SR1 but with anthropogenic NMVOC emissions within NA decreased by $20 \%$ \\
\hline SR6NA & $\begin{array}{l}\text { SR1 but with anthropogenic emissions of all } \mathrm{O}_{3} \text { precursors } \\
\left(\mathrm{NO}_{\mathrm{x}}+\mathrm{CO}+\mathrm{NMVOC}\right) \text { plus aerosols within NA decreased by } 20 \%\end{array}$ \\
\hline ISOPNA & SR1 but with isoprene emissions within NA increased by $20 \%$ \\
\hline SR6ISOPNA & SR6NA but with isoprene emissions within NA increased by $20 \%$ \\
\hline SR1_r100 & SR1 but with an isoprene nitrate recycling rate of $100 \%$ (up from $40 \%$ in SR1) \\
\hline SR6NA_r100 & SR6NA but with an isoprene nitrate recycling rate of $100 \%$ \\
\hline
\end{tabular}

Reidmiller et al., 2009; Jonson et al., 2010), generally captures observed distributions and seasonality over most regions. Notable exceptions include systematic high biases of 10-20 ppb in summertime surface $\mathrm{O}_{3}$ over the eastern United States and Japan, and systematic low biases of $\sim 15 \mathrm{ppb}$ at mountainous sites in the western US and Europe and at lowaltitude sites in the northeastern US and central Europe during winter. Most pertinent to our study is the model overestimate of summertime surface $\mathrm{O}_{3}$ over the eastern United States; this is pervasive across the current generation of CTMs (Fiore et al., 2009; Reidmiller et al., 2009) and investigations into its cause are ongoing. Although we do not yet understand the source(s) of this bias in surface $\mathrm{O}_{3}$, the lack of a simple relationship between model biases with respect to the observations and the simulated $\mathrm{O}_{3}$ responses to either domestic or intercontinental emission changes (Reidmiller et al., 2009; Jonson et al., 2010) suggests that additional tests are needed to evaluate the capability of models to adequately resolve the key processes governing intercontinental $\mathrm{O}_{3}$ pollution. Comparison with monthly mean PAN measured at mountain sites ( $2-4 \mathrm{~km}$ altitude) in western NA (Mt. Bachelor, Oregon, USA) and Europe (Jungfraujoch, Switzerland and Zugspitze, Germany) indicates that MOZART-2 falls within the observed range in most months, with a tendency to underestimate PAN from spring into early summer at the two European mountain sites (by 100-200 ppt; Fiore et al., 2011).

We presently lack observational constraints on the $\mathrm{O}_{3}$ response to emission perturbations, so we briefly summarize the comparison of MOZART-2 estimates with the multimodel mean in the HTAP studies. With respect to the intercontinental $\mathrm{O}_{3}$ response to the combined $20 \%$ decreases in anthropogenic $\mathrm{NO}_{\mathrm{x}}+\mathrm{CO}+\mathrm{NMVOC}+$ aerosols emissions, MOZART-2 estimates fall below the multi-model average (e.g., Fig. A2 of Fiore et al., 2009). The MOZART-2 annual $\mathrm{NO}_{\mathrm{y}}$ export fraction from NA is estimated to be 0.23 , slightly higher than the multi-model mean of 0.18 ; the summertime $\mathrm{NA} \mathrm{NO}_{\mathrm{y}}$ export fraction of 0.13 , more relevant for our study, is close to the multi-model mean (Sanderson et al., 2008; see their Table 1 and Fig. 2).
In order to examine the relative importance of isoprene versus anthropogenic $\mathrm{O}_{3}$ precursor emissions on hemispheric $\mathrm{O}_{3}$ levels, we conduct additional sensitivity simulations (Table 1). Relative to SR1, we impose a $20 \%$ increase in NA isoprene emissions (denoted ISOPNA). Our rationale for imposing oppositely signed perturbations to isoprene versus anthropogenic emissions is based on the strong temperature dependence of isoprene (which suggests that its emissions may increase in a warming climate), while we expect future efforts to abate air pollution to yield additional decreases in NA anthropogenic emissions. We note caveats on this scenario, which include the potential for rising carbon dioxide abundances or other factors to cause NA isoprene emissions to decline in future years (e.g., Rosenstiel et al., 2003; Avise et al., 2009; Chen et al., 2009) For context, the 20\% perturbation we impose on NA isoprene emissions is equivalent to observed year-to-year fluctuations, estimated at $\sim 20-30 \%$ from formaldehyde columns retrieved from space (Abbot et al., 2003; Palmer et al., 2006). The differences in $\mathrm{O}_{3}$ and PAN between ISOPNA and SR1 provides an estimate of the response to changes in NA isoprene (hereafter referred to as $\Delta \mathrm{O}_{3}$ ISOP and $\triangle \mathrm{PAN}$ ISOP) which can be compared directly with the response to the TF HTAP SR anthropogenic emission perturbations.

For testing the sensitivity of $\Delta \mathrm{O}_{3}$ ANTH in surface air (diagnosed by differencing SR1 and SR6NA) to isoprene emissions and their interactions with $\mathrm{NO}_{\mathrm{x}}$, we conduct three additional simulations: (1) a combined $20 \%$ increase in NA isoprene and 20\% decrease in NA anthropogenic emissions (SR6ISOPNA), (2) SR1 but with $100 \%$ recycling of $\mathrm{NO}_{\mathrm{x}}$ from isoprene nitrates (SR1_r100), and (3) SR6NA but with $100 \%$ isoprene nitrate recycling (SR6NA_r100). We use the difference between the SR6ISOPNA and SR1 simulations to gauge the potential impacts of a coincident $20 \%$ increase in NA isoprene and $20 \%$ decrease in all NA anthropogenic emissions, referred to hereafter as $\Delta \mathrm{O}_{3}$ _ANTHISOP and $\triangle$ PAN_ANTHISOP. The difference between these simulations also allows for an estimate of the "noise" associated with inter-annual variability in isoprene emissions surrounding the "signal" of a sustained reduction in NA anthropogenic 

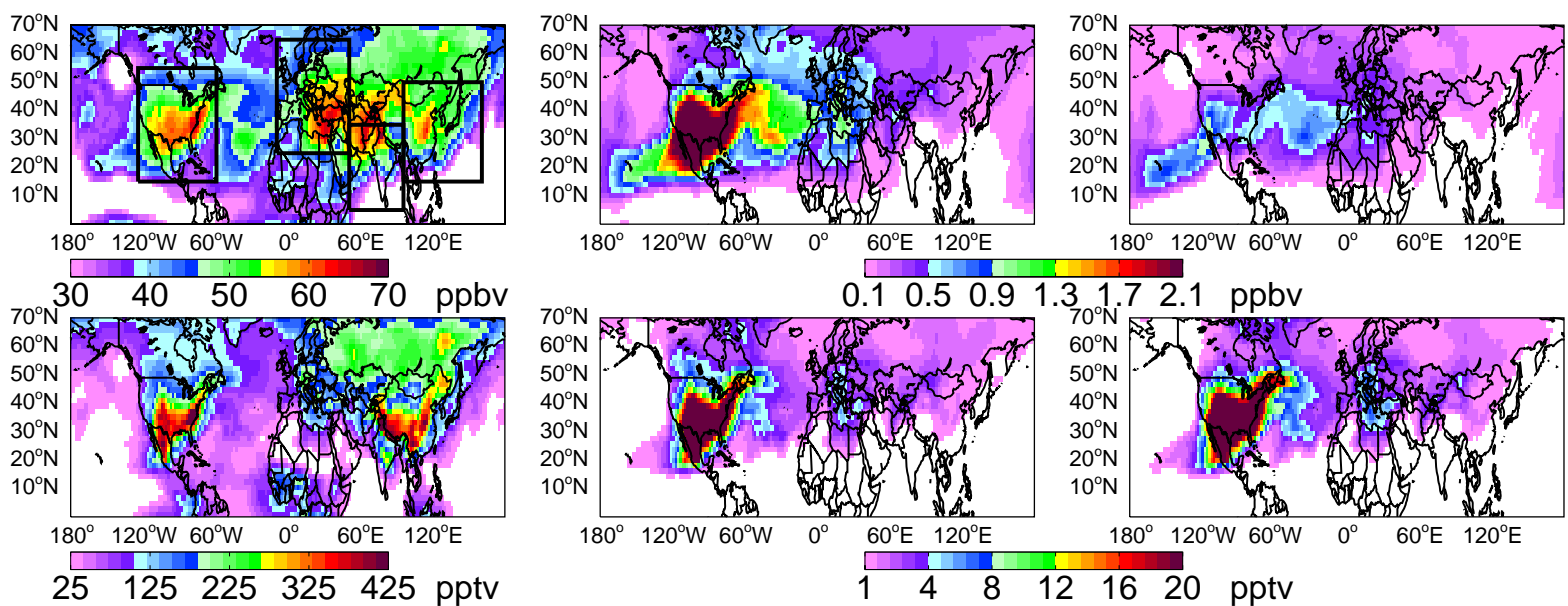

Fig. 2. Same as Fig. 1 but for $700 \mathrm{hPa}$.

emissions. Such an estimate is useful, for example, if one were trying to detect the influence of changes in NA emissions on $\mathrm{O}_{3}$. We next estimate the potential contribution of different baseline isoprene emission levels (ISOPNASR6ISOPNA) and different treatments of isoprene nitrate chemistry (SR1_r100-SR6NA_r100) to the model spread in $\Delta \mathrm{O}_{3}$ ANTH reported in Fiore et al. (2009) and for $\mathrm{NO}_{\mathrm{y}}$ deposition reported in Sanderson et al. (2008). Table 1 summarizes the model simulations used in this analysis.

\section{Hemispheric influence of NA isoprene and anthropogenic emissions in August}

Over foreign regions in the Northern Hemisphere, $\Delta \mathrm{O}_{3}$ ISOP is at least half as large (but opposite in sign) as $\triangle \mathrm{O}_{3}$ _ANTH during August (Fig. 1). The intercontinental $\triangle$ PAN_ISOP and $\triangle$ PAN_ANTH at the surface is negligible (Fig. 1), reflecting the strong thermal instability of PAN in warmer, surface air. The spatial patterns of the surface $\Delta \mathrm{O}_{3}$ _ISOP and $\Delta \mathrm{O}_{3}$ _ANTH correlate strongly $(r=0.71)$; both of these sources are predominantly located in eastern NA and are subject to the same meteorology which exports $\mathrm{O}_{3}$ from the NA continental boundary layer. NA emissions exert the largest intercontinental influence on Europe and North Africa (EU), the nearest downwind region, a robust result across models (Fiore et al., 2009).

We next examine changes in $\mathrm{O}_{3}$ and PAN at the model level centered at $694 \mathrm{hPa}$, hereafter referred to as " $700 \mathrm{hPa",}$ for two reasons: (1) this level should reside in the lower free troposphere and thus reflect the composition of air masses that are available to subside and mix into the continental boundary layer, and (2) this altitude is a region of the atmosphere that can be sampled with ground-based instruments in mountainous regions. At $700 \mathrm{hPa}$ in August, $\triangle$ PAN_ISOP and $\triangle$ PAN_ANTH are more strongly correlated spatially $\left(r=0.99 ;\right.$ Fig. 2) than $\Delta \mathrm{O}_{3}$ ISOP and $\Delta \mathrm{O}_{3}$ ANTH $(r=$ 0.81 ). Both at the surface and at $700 \mathrm{hPa}, \Delta \mathrm{O}_{3}$-ANTH is generally larger in magnitude than $\Delta \mathrm{O}_{3}$ ISOP (Figs. 1, 2 and 3). In contrast, the $700 \mathrm{hPa} \triangle \mathrm{PAN}$.ISOP is equivalent in magnitude or larger than $\triangle$ PAN_ANTH Figs. 2 and 3). The slightly larger $\triangle$ PAN_ISOP at $700 \mathrm{hPa}$ over the EU region may partially reflect the transport of hydroxyacetone, an intermediate isoprene oxidation product with a lifetime of days, which further reacts to produce methyl glyoxal and the peroxy acetyl radical, which may lead to additional PAN formation in the presence of $\mathrm{NO}_{\mathrm{x}}$ (e.g., from regional emissions; not shown). These results demonstrate the key role that isoprene plays in PAN formation at northern mid-latitudes in summer (Horowitz et al., 1998; Pfister et al., 2008). If we extrapolate the results in Fig. 3 assuming that PAN responds linearly to isoprene emission changes (i.e., multiplying the response to a $20 \%$ perturbation by five to estimate $100 \%$ contribution), then we estimate that up to $25 \%$ of $700 \mathrm{hPa}$ PAN over Spain, the Mediterranean and Northern Africa in August is associated with NA isoprene emissions.

Since isoprene influences the $\mathrm{NO}_{\mathrm{y}}$ partitioning between organic nitrates and nitric acid, we also examine the impacts of anthropogenic versus isoprene emission changes on $\mathrm{NO}_{\mathrm{y}}$ deposition (Fig. 3). The changes from NA anthropogenic emissions are similar to those reported for the $\mathrm{NA} \mathrm{NO}_{\mathrm{x}}$ perturbations in Sanderson et al. (2008), with changes in deposition largely concentrated within the source region, and small (a few percent) changes in the foreign TFHTAP regions. The NA isoprene influence on $\mathrm{NO}_{\mathrm{y}}$ deposition in the foreign TFHTAP regions is less than $1 \%$. Over $\mathrm{NA}, \mathrm{NO}_{\mathrm{y}}$ deposition decreases when isoprene emissions increase since isoprene is a direct precursor to the peroxy acetyl radical, thus favoring PAN formation relative to nitric acid $\left(\mathrm{HNO}_{3}\right)$; the decrease in $\mathrm{OH}$ associated with increasing isoprene emissions in the model would also tend to decrease $\mathrm{HNO}_{3}$ production (Horowitz et al., 1998). We emphasize that the influence of 

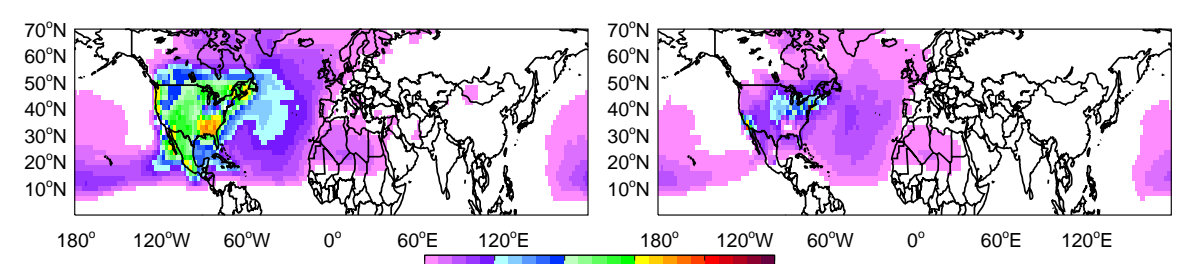

$\begin{array}{lllllll}0.5 & 2.5 & 4.5 & 6.5 & 8.5 & 10.5 & \% \\ 0 & \text { change surface } \mathrm{O}_{3}\end{array}$

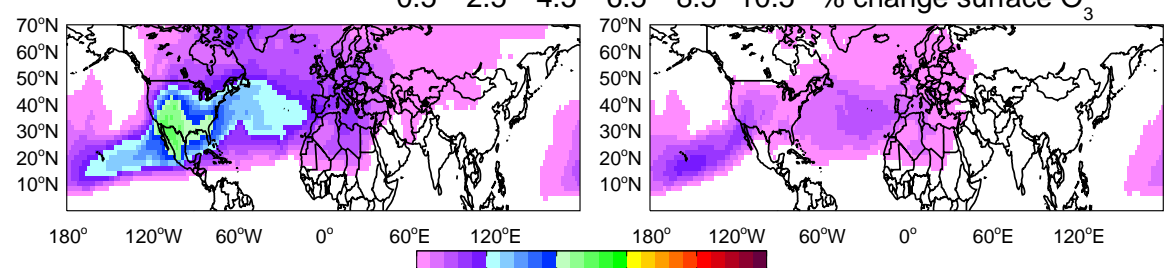

$\begin{array}{lllllll}0.5 & 2.5 & 4.5 & 6.5 & 8.5 & 10.5 & \%\end{array}$ change $700 \mathrm{hPa} \mathrm{O}_{3}$

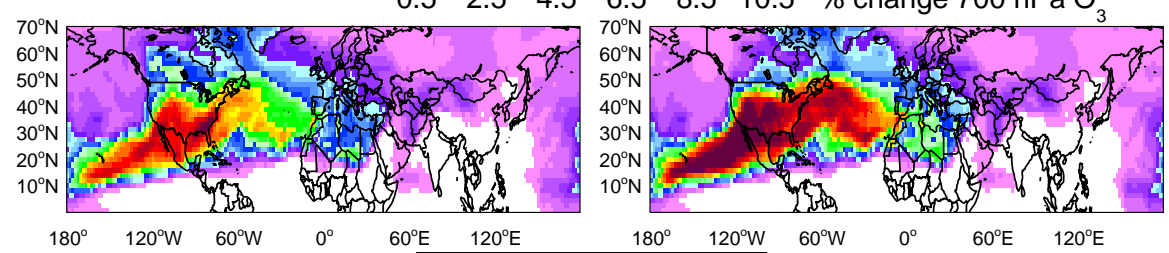

\begin{tabular}{lllllll}
0.5 & 2.5 & 4.5 & 6.5 & 8.5 & 10.5 & $\%$ \\
\hline
\end{tabular}

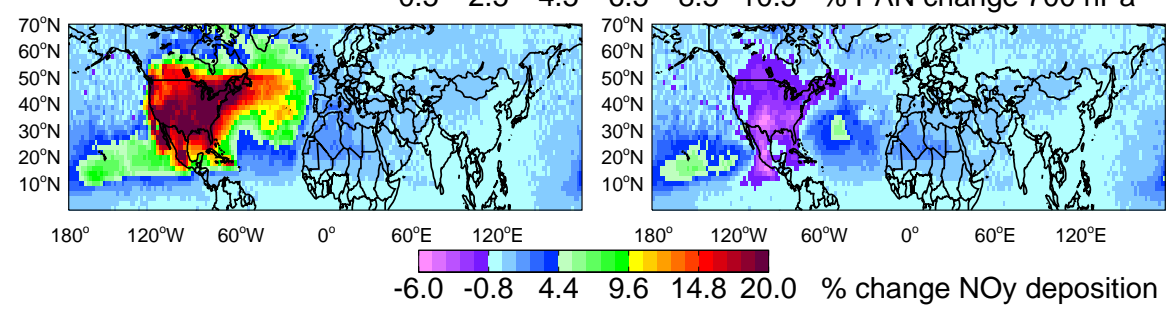

Fig. 3. Percentage decrease (left) and increase (right) in surface $\mathrm{O}_{3}$ (first row), $\mathrm{O}_{3}$ at $700 \mathrm{hPa}$ (second row), $\mathrm{PAN}$ at $700 \mathrm{hPa}$ (third row), and $\mathrm{NO}_{\mathrm{y}}$ deposition (bottom row) resulting from $20 \%$ decreases in NA anthropogenic $\mathrm{O}_{3}$ precursor emissions (SR1-SR6NA simulations; left) and $20 \%$ increases in biogenic isoprene emissions (ISOPNA-SR1; right) in the MOZART-2 model during August of 2001. Note the different scales on each color bar. Areas in white fall below the minimum value shown.

isoprene on $\mathrm{OH}$ is the subject of much debate and ongoing research and is likely not well represented in mechanisms available in current generation CTMs (e.g., Lelieveld et al., 2008; Ren et al., 2008; Paulot et al., 2009; Archibald et al., 2010). Nevertheless, we see from Fig. 3 the interaction of isoprene oxidation products with meteorology, which leads to more $\mathrm{NO}_{\mathrm{y}}$ deposition in the North Atlantic and North Pacific oceans. These regions are influenced by PAN decomposition in air masses that subside as they circulate around the Bermuda and Pacific high pressure systems, and the subsequent deposition of that nitrogen (mainly as $\mathrm{HNO}_{3}$ ).

\section{Seasonal variations in regional and intercontinental influences of NA emissions}

We turn next to seasonal variations in the surface $\mathrm{O}_{3}$ and lower free tropospheric PAN responses to changes in NA isoprene versus anthropogenic emissions. Following the approach of Fiore et al. (2009), we construct monthly SR re- lationships for surface $\mathrm{O}_{3}$ and PAN at $700 \mathrm{hPa}$ by spatially averaging over the continental-scale regions (Fig. 4). We focus on the NA and EU regions to illustrate "regional" versus "intercontinental" responses. We note that the average values in Fig. 4 mask a large sub-regional variability in the $\mathrm{O}_{3}$ response to emission perturbations (Reidmiller et al., 2009; Lin et al., 2010), evident in Figs. 1, 2 and 3. Increases in isoprene consistently act to depress local $\mathrm{NO}_{\mathrm{y}}$ deposition but increase intercontinental $\mathrm{NO}_{\mathrm{y}}$ deposition as seen in Fig. 3 (bottom row) throughout the isoprene emission season (not shown) and so we focus on seasonal variations in $\mathrm{O}_{3}$ and PAN in this section.

Over the NA and EU regions, $\Delta \mathrm{O}_{3}$ ISOP in surface air (Fig. 4) is enhanced in autumn relative to spring, despite similar emissions in the two seasons $(\sim 4 \mathrm{Tg} C$ in May and September, and $\sim 2 \mathrm{Tg} C$ in April and October). In contrast, the seasonal cycle of $\Delta \mathrm{O}_{3}$ ANTH tends to be more symmetrically centered on the summer months (Fig. 4); those emissions do not vary seasonally in the model so the $\mathrm{O}_{3}$ responses are only influenced by seasonal changes in transport 

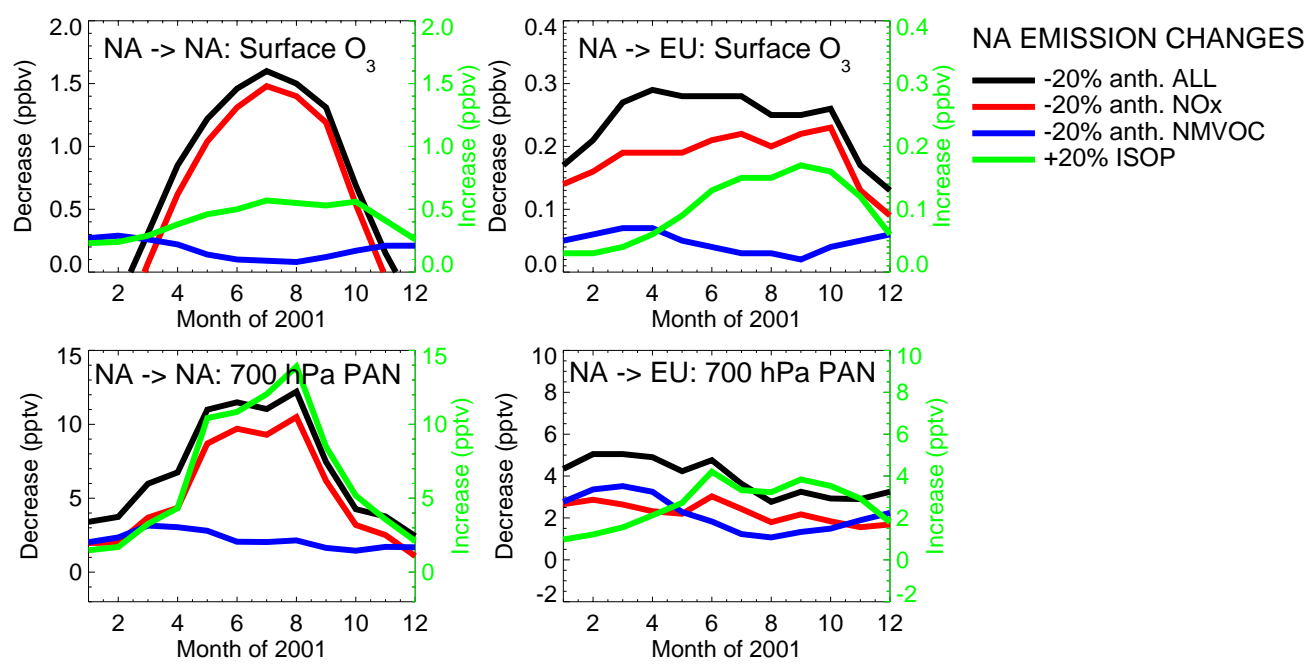

Fig. 4. Monthly mean regional (left) and intercontinental (right) $\Delta \mathrm{O}_{3}$ _ANTH in surface air (top) and $\triangle \mathrm{PAN}$-ANTH at $700 \mathrm{hPa}$ (bottom), as determined by differencing the spatially averaged surface $\mathrm{O}_{3}$ over NA and $\mathrm{EU}$ (Fig. 1) in the baseline simulation and in sensitivity simulations in which NA anthropogenic emissions of $\mathrm{NO}_{\mathrm{x}}$ (red), $\mathrm{NMVOC} \mathrm{(blue),} \mathrm{and} \mathrm{all} \mathrm{O}_{3}$ precursors combined (black) are decreased by $20 \%$ (left axis). Also shown are $\Delta \mathrm{O}_{3}$ IISOP and $\triangle \mathrm{PAN}$ ISOP (green; right axis).

and photochemistry. The larger $\Delta \mathrm{O}_{3}$ ISOP in autumn relative to spring is consistent with a transition in $\mathrm{O}_{3}$ formation from $\mathrm{NO}_{\mathrm{x}}$-sensitive to hydrocarbon-sensitive over the eastern United States in September, resulting from the seasonal decline in UV radiation (maximum in June) and humidity (maximum in summer) (Kleinman, 1991; Jacob et al., 1995; Liang et al., 1998).

Whereas surface (and $700 \mathrm{hPa}$ ) $\mathrm{O}_{3}$ responds more strongly to equivalent percentage changes in anthropogenic $\mathrm{NO}_{\mathrm{x}}$ than to isoprene emissions (Fig. 4; see also Fig. 3), the opposite is true for $700 \mathrm{hPa}$ PAN during May through December. Furthermore, the regional $\triangle$ PAN_ISOP at $700 \mathrm{hPa}$ exceeds that to $\triangle$ PAN_ANTH in August (Fig. 4) and is approximately equal in other non-winter months; the intercontinental response is equivalent from June through October. Imposing equivalent percentage reductions to NA isoprene and anthropogenic NMVOC emissions yields stronger $\mathrm{O}_{3}$ and PAN responses for the isoprene perturbation over both regions from spring through late fall (Fig. 4), as expected since the absolute perturbation is an order of magnitude larger for isoprene. Even in winter, NA isoprene contributes to hemispheric $\mathrm{O}_{3}$ and PAN, likely due to production from emissions in the southern-most portion of the NA domain as well as the longer chemical lifetimes during this season (e.g., Wang et al., 1998).

\section{PAN as a proxy for regional changes in $\mathrm{O}_{3}$ precursor emissions}

We explore here the potential for PAN to indicate $\mathrm{O}_{3}$ precursor emission changes. Both NA anthropogenic and isoprene emission changes exert a larger relative influence on PAN, both at the surface and at $700 \mathrm{hPa}$, as compared to $\mathrm{O}_{3}$ (Fig. 3). Indeed, outside of the NA source region, both $\triangle$ PAN_ANTH and $\triangle$ PAN_ISOP are more than twice as large as $\Delta \mathrm{O}_{3}{ }_{-} \mathrm{ANTH}$ and $\Delta \mathrm{O}_{3}$ ISOP, with larger changes extending over wider regions.

This finding supports the premise of Jaffe et al. (2007) and Fischer et al. (2011), that long-term PAN observations at remote sites may be more useful than $\mathrm{O}_{3}$ itself in detecting large-scale trends in $\mathrm{O}_{3}$ precursor emissions. Fischer et al. (2011), however, estimate that the larger variability in PAN observed at the Mount Bachelor site in western NA compensates for the larger relative signal such that the same length of time is needed to determine an emission-driven trend in $\mathrm{O}_{3}$ as for PAN. Given that measured $\mathrm{O}_{3}$ can additionally be influenced by changes in the stratospheric $\mathrm{O}_{3}$ source and chemical losses (whereas the major sink for PAN in the lower troposphere is thermal decomposition), it may be desirable to establish a few key long term sites to measure PAN, ideally with coincident $\mathrm{O}_{3}$ measurements, to aid in detecting changes in $\mathrm{O}_{3}$ that can be attributed with confidence to regional changes in $\mathrm{O}_{3}$ precursor emissions. For example, Fig. 3 suggests that long-term observations at the Pico station in the Azores could identify changes in NA anthropogenic and biogenic emissions (Honrath et al., 2004). Such measurements would also provide much needed constraints on major uncertainties in PAN formation chemistry 

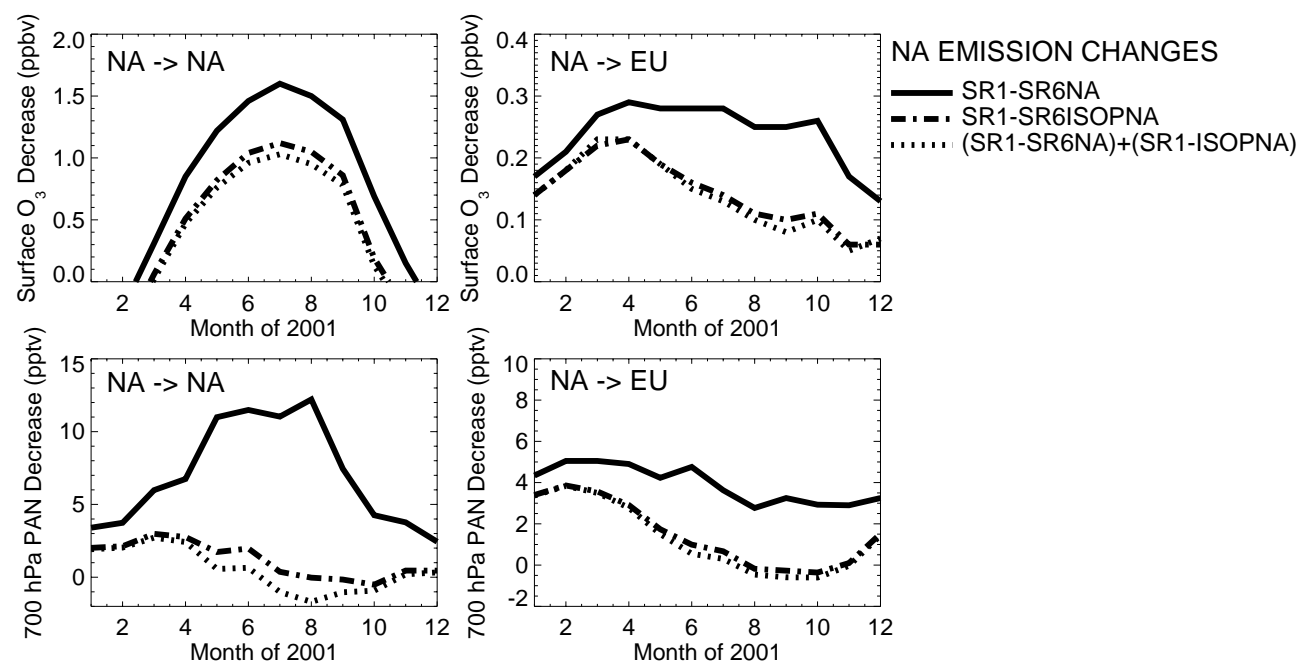

Fig. 5. Monthly mean regional (left) and intercontinental (right) $\Delta \mathrm{O}_{3} \_\mathrm{ANTH}$ (solid; as in Fig. 4) and $\Delta \mathrm{O}_{3} \_\mathrm{ANTHISOP}$ (dash-dot) in surface air (top), and $\triangle$ PAN_ANTH (solid; as in Fig. 4) and $\triangle$ PAN_ANTHISOP (dash-dot) at $700 \mathrm{hPa}$ (bottom), diagnosed as the difference between sensitivity simulations as in Fig. 4. Also shown are $\Delta \mathrm{O}_{3} \_$ANTH $+\Delta \mathrm{O}_{3}$ ISOP and $\Delta$ PAN_ANTH+ $\Delta$ PAN_ISOP (dotted).

as represented in chemical mechanisms (Kuhn et al., 1998; Emmerson and Evans, 2009; Henderson et al., 2011).

Our findings further suggest that the role of isoprene must be carefully considered alongside that of anthropogenic emissions in interpreting observed changes in PAN. We use the difference between the SR6ISOPNA and SR1 simulations to estimate the "noise" associated with trying to detect the "signal" of $\Delta \mathrm{O}_{3} \_\mathrm{ANTH}$ or $\triangle \mathrm{PAN} \_\mathrm{ANTH}$ over Europe in light of year-to-year variability in isoprene emissions. For this calculation, we first note that our NA isoprene perturbation simulation captures the full range of inter-annual isoprene variability observed in formaldehyde columns from space (Abbot et al., 2003; Palmer et al., 2006). Second, our simulations use climatologically average isoprene emissions. Third, we assume that surface $\mathrm{O}_{3}$ responds approximately linearly to NA isoprene emission perturbations of $20 \%$ as occurs for anthropogenic NMVOC and for small perturbations (generally within 20\%) to anthropogenic $\mathrm{NO}_{\mathrm{x}}$ (Fiore et al., 2009; Wu et al., 2009). Our finding that $\Delta \mathrm{O}_{3}$ ANTHISOP is half of $\Delta \mathrm{O}_{3}$ ANTH over EU in summer (Fig. 5 upper panels) can thus be interpreted as a variability of $\pm 25 \%$ relative to the climatologically average isoprene emissions (i.e., $\pm 25 \%$ variations relative to our $\Delta \mathrm{O}_{3}$ ANTH estimate determined from SR1-SR6NA; Figs. 4 and 5). In a similar manner, we estimate that inter-annual variability in NA isoprene emissions can induce fluctuations of $\pm 50 \%$ around the decrease in EU $\triangle$ PAN_ANTH at $700 \mathrm{hPa}$.

Unraveling the relative contributions of $\mathrm{NO}_{\mathrm{x}}$ versus isoprene or other NMVOC to observed variability in measured PAN requires additional source information, including a solid understanding of isoprene emission variations (near equivalence of red and green lines in Fig. 4). While iso- prene clearly dominates over anthropogenic NMVOC with regard to PAN formation in the model in summer and fall, anthropogenic NMVOC precursors to PAN are likely important in some regions (e.g., Liu et al., 2010) as well as outside the isoprene emission season. In this regard, long-term measurements that can distinguish changes in the biogenic and anthropogenic sources of carbon and nitrogen alongside PAN concentrations would be valuable. For example, coincident measurements of individual PAN species (MPAN and PPN) have enabled attribution of anthropogenic versus biogenic carbon contributions to PAN and $\mathrm{O}_{3}$ during groundbased, ship and aircraft field intensives (Roberts et al., 1998, 2002, 2006).

\section{Estimating NA anthropogenic influence: uncertainty due to isoprene emissions and chemistry}

We first estimate the degree to which NA isoprene emission increases, as might be induced by changes in climate or land-use (e.g., Sanderson et al., 2003; Wiedinmyer et al., 2006; Weaver et al., 2009), would offset the decreases in surface $\mathrm{O}_{3}$ resulting from NA anthropogenic emission controls. The difference between $\Delta \mathrm{O}_{3}$-ANTH and $\Delta \mathrm{O}_{3}$ ANTHISOP (Fig. 5) provides an estimate of the offset. We do not consider changes in the spatial distribution of isoprene emissions relative to the simple, uniform scaling applied here, which may also alter the surface $\mathrm{O}_{3}$ response to anthropogenic emissions. When isoprene increases by $20 \%$ in the model, $\Delta \mathrm{O}_{3}$ ANTH is offset by approximately half over foreign regions and by one third over the NA region from summer into fall. This result, taken in isolation, implies that additional controls on anthropogenic emissions would be needed 
to sustain a desired level of hemispheric $\mathrm{O}_{3}$ abatement if isoprene emissions increase. We note that other changes in a warmer climate (e.g., more water vapor) not considered here are expected to lessen the overall intercontinental influence (e.g., Johnson et al., 1999; Murazaki and Hess, 2006; TFHTAP, 2007). We further note that the combined impact of $\mathrm{NA}$ isoprene and anthropogenic emission perturbations can be approximated by adding the differences between pairs of simulations in which we perturbed those emissions individually (Fig. 5). This additivity was previously shown to occur for the surface $\mathrm{O}_{3}$ responses to anthropogenic $\mathrm{NO}_{\mathrm{x}}, \mathrm{CO}$, and NMVOC emission perturbations (Fiore et al., 2009). The larger divergence from additivity over the immediate source region as compared to intercontinental distances (particularly evident for PAN in Fig. 5) is consistent with the findings of Wild and Prather (2006).

Prior work has demonstrated a large sensitivity of surface $\mathrm{O}_{3}$ to the choice of isoprene emission inventories and the fate of nitrates formed during isoprene oxidation (Horowitz et al., 1998; Kang et al., 2003; von Kuhlmann et al., 2004; Fiore et al., 2005; Ito et al., 2009). Evaluation of eastern US isoprene emission inventories with observations suggests an uncertainty of within a factor of two (Warneke et al., 2010). We do not have a good estimate of the range of NA isoprene emissions in the models participating in the TF HTAP study, but we expect that the $20 \%$ increase in NA isoprene emissions that we imposed is conservative and so the range of responses is likely significantly larger than that shown in Figs 1, 2 and 3 (right columns). In Fig. 6, we illustrate the changes in the baseline simulations resulting from increasing the isoprene nitrate recycling from $40 \%$ to $100 \%$ during August. Doubling the response to isoprene nitrate recycling to approximate the full range of 0 to $100 \%$ recycling as occurs in current CTMs (e.g., Fiore et al., 2005), we estimate uncertainty ranges (reflecting spatial variability) of 2-6 ppb, 10-50 ppt, and 5-20\% in surface $\mathrm{O}_{3}, 700 \mathrm{hPa} P A N$ and $\mathrm{NO}_{\mathrm{y}}$ deposition, respectively, over the NA region in August (Fig. 6). These findings are consistent with earlier work (von Kuhlmann et al., 2004; Fiore et al., 2005).

We next determine the impact of these uncertainties in isoprene emissions and isoprene nitrate fate on estimates of $\Delta \mathrm{O}_{3}$ ANTH. Figure 7 shows that neither a $20 \%$ increase in the baseline NA isoprene emissions nor an increase in the $\mathrm{NO}_{\mathrm{x}}$ recycling from isoprene nitrates changes $\Delta \mathrm{O}_{3} \mathrm{ANTH}$ significantly in surface air over the NA or EU regions. Clearly the differences in Fig. 7 cannot explain the factor of 2-3 spread in EU surface $\Delta \mathrm{O}_{3}$ ANTH across models reported in Fiore et al. (2009) and Reidmiller et al. (2009). This lack of sensitivity indicates that the dependence of $\mathrm{O}_{3}$ production on precursor emissions, at least for the $20 \%$ decreases to NA anthropogenic emissions considered here, is not changed by perturbations to isoprene- $\mathrm{NO}_{\mathrm{x}}-\mathrm{O}_{3}$ chemistry.

A modest nonlinear response does emerge for PAN, with larger $\triangle \mathrm{PAN} \_$ANTH in the simulations with higher isoprene emissions. This response reflects the strong sensitivity of

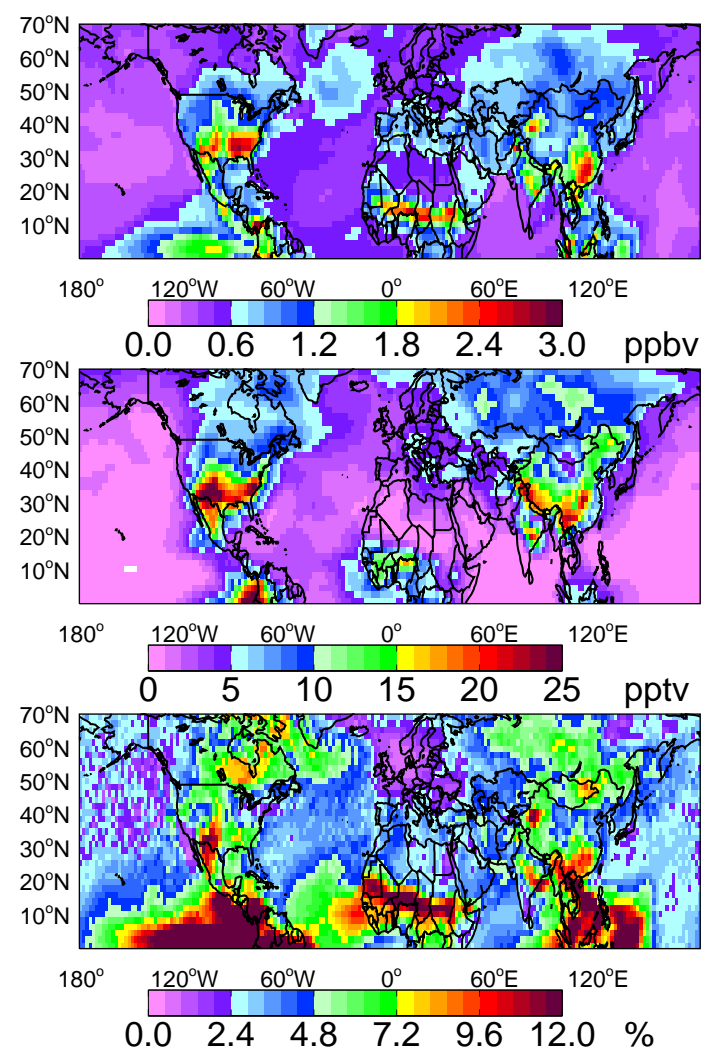

Fig. 6. Change in August mean surface $\mathrm{O}_{3}$ (top), lower free tropospheric PAN (middle), and $\mathrm{NO}_{\mathrm{y}}$ deposition (bottom) when global isoprene nitrate recycling increases from $40 \%$ to $100 \%$ (SR1_r100SR1).

PAN formation to the production of peroxy acetyl radicals from isoprene as well as the ratio of $\mathrm{NO}$ to $\mathrm{NO}_{2}$ and the key role of $\mathrm{OH}$ levels in this partitioning. This sensitivity implies that models with higher baseline isoprene emissions may amplify $\triangle$ PAN_ANTH. In contrast, the $\mathrm{NO}_{\mathrm{y}}$ deposition sensitivity, defined as the change in total (wet plus dry) $\mathrm{NO}_{\mathrm{y}}$ deposition over a region divided by the change in $\mathrm{NA} \mathrm{NO}_{\mathrm{x}}$ emissions (Sanderson et al., 2008), is relatively insensitive to the uncertainties in isoprene emissions and chemistry tested here. The maximum difference among pairs of simulations is $2 \%$ over NA and $0.06 \%$ over EU in summer (bottom panels of Fig. 7). Even if the full range of uncertainty would allow for a doubling of these values, they are still insufficient to explain the $5 \%$ and $0.8 \%$ standard deviations (full ranges of $10 \%$ and $1.6 \%$ ) reported across models (Sanderson et al., 2008).

\section{Conclusions}

With the MOZART-2 global chemical transport model, we examined the influence of isoprene versus anthropogenic emissions from North America (NA) on intercontinental $\mathrm{O}_{3}$ 

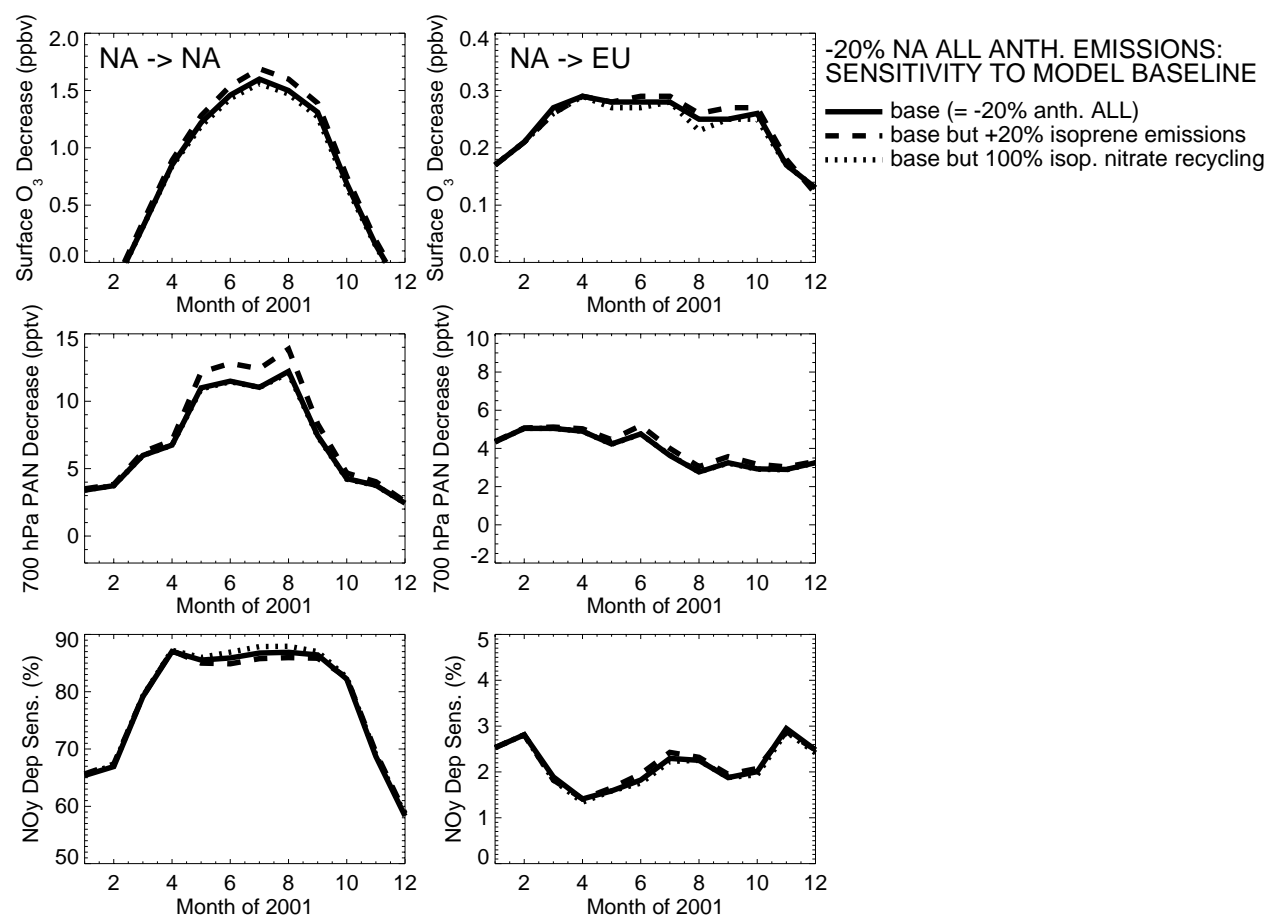

Fig. 7. The monthly mean regional (left) and intercontinental (right) $\Delta \mathrm{O}_{3} \_\mathrm{ANTH}$ in surface air (top), $\triangle \mathrm{PAN} \_\mathrm{ANTH}$ at $700 \mathrm{hPa}$ (middle), and $\mathrm{NO}_{\mathrm{y}}$ deposition sensitivity (bottom) with different model baselines: as in Fig. 4 (solid; SR1-SR6NA), with NA isoprene emissions increased by $20 \%$ (dashed; ISOPNA-SR6ISOPNA), and with the isoprene nitrate recycling rate increased from $40 \%$ (as in SR1) to $100 \%$ (dotted; SR1_r100-SR6NA_r100). $\mathrm{NO}_{\mathrm{y}}$ deposition sensitivity is defined as the regional change in $\mathrm{NO}_{\mathrm{y}}$ deposition divided by the change in $\mathrm{NA} \mathrm{NO}_{\mathrm{x}}$ emissions (Sanderson et al., 2008).

pollution, PAN at $700 \mathrm{hPa}$ and oxidized nitrogen deposition. Sensitivity simulations in the model indicate that any increases in isoprene, whether induced by a warming climate or changing land-use practices, could offset the regional and intercontinental surface $\mathrm{O}_{3}$ decreases produced by controls on NA anthropogenic emissions during the summer through fall. These results imply a need to include the role of biogenic NMVOC alongside that of anthropogenic emissions in discussions of hemispheric air pollution management. In addition to raising hemispheric $\mathrm{O}_{3}$ levels, biogenic isoprene emissions enhance organic aerosol burdens in the atmosphere with corresponding implications for climate and air quality (e.g., Carlton et al., 2009). In light of the potentially large impacts on biogenic emissions, plausible land-use options merit inclusion in anthropogenic emission scenarios used to project future air quality and climate (e.g., Wiedinmyer et al., 2006; Avise et al., 2009).

We further interpret our findings to show that long-term, continuous observations of PAN in the lower free troposphere may prove useful in detecting $\mathrm{O}_{3}$ precursor emission changes. We find that the role of isoprene should be carefully considered if one is attributing observed changes in PAN (or $\mathrm{O}_{3}$ ) to anthropogenic emission changes. Long-term PAN measurements would also provide crucial constraints on our uncertain understanding of PAN formation chemistry (Kuhn et al., 1998; Emmerson and Evans, 2009; Henderson et al., 2011).

The simulated hemispheric responses of surface $\mathrm{O}_{3}$ and oxidized nitrogen deposition to regional anthropogenic emission perturbations show little sensitivity to the level of isoprene emissions specified in the model (within the $20 \%$ uncertainty range considered here) or the extent to which isoprene nitrates serve as a terminal sink for $\mathrm{NO}_{\mathrm{x}}$. Although these uncertainties do contribute to the range in model estimates of surface $\mathrm{O}_{3}$ and the tropospheric $\mathrm{O}_{3}$ budget (von Kuhlmann et al., 2004; Wu et al., 2007), we find that they are not a major driver of the inter-model spread in the responses of surface $\mathrm{O}_{3}$ or oxidized nitrogen deposition to anthropogenic emission perturbations estimated in the TFHTAP studies (TFHTAP, 2007; Sanderson et al., 2008; Fiore et al., 2009; Reidmiller et al., 2009).

Acknowledgements. We thank M. Lin (Princeton), B. Duncan (NASA GSFC), and L. Horowitz (NOAA GFDL) for thoughtful comments on an earlier draft, M. Evans (Leeds), E. Fischer (U Washington) and J. Orlando (NCAR) for useful discussions, two anonymous reviewers, and the editor.

Edited by: D. Simpson 


\section{References}

Abbot, D. S., Palmer, P. I., Martin, R. V., Chance, K. V., Jacob, D. J., and Guenther, A.: Seasonal and interannual variability of North American isoprene emissions as determined by formaldehyde column measurements from space, Geophys. Res. Lett., 30, 1886, doi:10.1029/2003g1017336, 2003.

Anenberg, S. C., West, J. J., Fiore, A. M., Jaffe, D. A., Prather, M. J., Bergmann, D., Cuvelier, K., Dentener, F. J., Duncan, B. N., Gauss, M., Hess, P., Jonson, J. E., Lupu, A., MacKenzie, I. A., Marmer, E., Park, R. J., Sanderson, M. G., Schultz, M., Shindell, D. T., Szopa, S., Vivanco, M. G., Wild, O., and Zeng, G.: Intercontinental Impacts of Ozone Pollution on Human Mortality, Environ. Sci. Technol., 43, 6482-6487, doi:10.1021/es900518z, 2009.

Archibald, A. T., Cooke, M. C., Utembe, S. R., Shallcross, D. E., Derwent, R. G., and Jenkin, M. E.: Impacts of mechanistic changes on HOx formation and recycling in the oxidation of isoprene, Atmos. Chem. Phys., 10, 8097-8118, doi:10.5194/acp10-8097-2010, 2010.

Arneth, A., Monson, R. K., Schurgers, G., Niinemets, ., and Palmer, P. I.: Why are estimates of global terrestrial isoprene emissions so similar (and why is this not so for monoterpenes)?, Atmos. Chem. Phys., 8, 4605-4620, doi:10.5194/acp-8-4605-2008, 2008.

Avise, J., Chen, J., Lamb, B., Wiedinmyer, C., Guenther, A., Salathé, E., and Mass, C.: Attribution of projected changes in summertime US ozone and $\mathrm{PM}_{2.5}$ concentrations to global changes, Atmos. Chem. Phys., 9, 1111-1124, doi:10.5194/acp9-1111-2009, 2009.

Carlton, A. G., Wiedinmyer, C., and Kroll, J. H.: A review of Secondary Organic Aerosol (SOA) formation from isoprene, Atmos. Chem. Phys., 9, 4987-5005, doi:10.5194/acp-9-4987-2009, 2009.

Chameides, W. L., Lindsay, R. W., Richardson, J., and Kang, C. S.: The role of biogenic hydrocarbons in urban smog: Atlanta as a case study, Science, 241, 1473-1475, 1988.

Chen, J., Avise, J., Lamb, B., Salath, E., Mass, C., Guenther, A., Wiedinmyer, C., Lamarque, J.-F., O’Neill, S., McKenzie, D., and Larkin, N.: The effects of global changes upon regional ozone pollution in the United States, Atmos. Chem. Phys., 9, 11251141, doi:10.5194/acp-9-1125-2009, 2009.

Dollard, G. J., Dumitrean, P., Telling, S., Dixon, J., and Derwent, R. G.: Observed trends in ambient concentrations of C2-C8 hydrocarbons in the United Kingdom over the period from 1993 to 2004, Atmos. Environ., 41, 2559-2569, 2007.

Emmerson, K. M. and Evans, M. J.: Comparison of tropospheric gas-phase chemistry schemes for use within global models, Atmos. Chem. Phys., 9, 1831-1845, doi:10.5194/acp-9-1831-2009, 2009.

Emmons, L. K., Walters, S., Hess, P. G., Lamarque, J.-F., Pfister, G. G., Fillmore, D., Granier, C., Guenther, A., Kinnison, D., Laepple, T., Orlando, J., Tie, X., Tyndall, G., Wiedinmyer, C., Baughcum, S. L., and Kloster, S.: Description and evaluation of the Model for Ozone and Related chemical Tracers, version 4 (MOZART-4), Geosci. Model Dev., 3, 43-67, doi:10.5194/gmd3-43-2010, 2010.

Fang, Y., Fiore, A. M., Horowitz, L. W., Levy II, H., Hu, Y., and Russell, A. G.: Sensitivity of the NOy budget over the United
States to anthropogenic and lightning $\mathrm{NO}_{\mathrm{x}}$ in summer, J. Geophys. Res., D18, D18312, doi:10.1029/2010jd014079, 2010.

Fiore, A. M., Horowitz, L. W., Purves, D. W., Levy, H., II, Evans, M. J., Wang, Y., Li, Q., and Yantosca, R. M.: Evaluating the contribution of changes in isoprene emissions to surface ozone trends over the eastern United States, J. Geophys. Res., 110, D12303, doi:10.1029/2004jd005485, 2005.

Fiore, A. M., Dentener, F. J., Wild, O., Cuvelier, C., Schultz, M. G., Hess, P., Textor, C., Schulz, M., Doherty, R. M., Horowitz, L. W., MacKenzie, I. A., Sanderson, M. G., Shindell, D. T., Stevenson, D. S., Szopa, S., Van Dingenen, R., Zeng, G., Atherton, C., Bergmann, D., Bey, I., Carmichael, G., Collins, W. J., Duncan, B. N., Faluvegi, G., Folberth, G., Gauss, M., Gong, S., Hauglustaine, D., Holloway, T., Isaksen, I. S. A., Jacob, D. J., Jonson, J. E., Kaminski, J. W., Keating, T. J., Lupu, A., Marmer, E., Montanaro, V., Park, R. J., Pitari, G., Pringle, K. J., Pyle, J. A., Schroeder, S., Vivanco, M. G., Wind, P., Wojcik, G., Wu, S., and Zuber, A.: Multimodel estimates of intercontinental sourcereceptor relationships for ozone pollution, J. Geophys. Res., 114, D04301, doi:10.1029/2008jd010816, 2009.

Fiore, A. M., Fischer, E. V., Jaffe, D. J., Pandey, S., and Staehelin, J.: Hemispheric and regional pollution signatures in PAN at northern mid-latitude mountain sites, in preparation, 2011.

Fischer, E. V., Jaffe, D. A., Reidmiller, D. R., and Jaegle, L.: Meteorological controls on observed peroxyacetyl nitrate (PAN) at Mount Bachelor during the spring of 2008, J. Geophys. Res., 115, D03302, doi:10.1029/20092009JD20012776, 2010.

Fischer, E. V., Jaffe, D. A., and Weatherhead, E. C.: Free tropospheric peroxyacetyl nitrate (PAN) and ozone at Mount Bachelor: causes of variability and timescale for trend detection, Atmos. Chem. Phys. Discuss., 11, 4105-4139, doi:10.5194/acpd11-4105-2011, 2011.

Folberth, G. A., Hauglustaine, D. A., Lathière, J., and Brocheton, F.: Interactive chemistry in the Laboratoire de Mtorologie Dynamique general circulation model: model description and impact analysis of biogenic hydrocarbons on tropospheric chemistry, Atmos. Chem. Phys., 6, 2273-2319, doi:10.5194/acp-62273-2006, 2006.

Fuentes, J. D., Lerdau, M., Atkinson, R., Baldocchi, D., Bottenheim, J. W., Ciccioli, P., Lamb, B., Geron, C., Gu, L., Guenther, A., Sharkey, T. D., and Stockwell, W.: Biogenic Hydrocarbons in the Atmospheric Boundary Layer: A Review, B. Am. Meteor. Soc., 81, 1537-1575, 2000.

Guenther, A., Hewitt, C. N., Erickson, D., Fall, R., Geron, C., Graedel, T., Harley, P., Klinger, L., Lerdau, M., McKay, W. A., Pierce, T., Scholes, B., Steinbrecher, R., Tallamraju, R., Taylor, J., and Zimmerman, P.: A global model of natural volatile organic compound emissions, J. Geophys. Res., 100, 8873-8892, doi:10.1029/94jd02950, 1995.

Guenther, A., Karl, T., Harley, P., Wiedinmyer, C., Palmer, P. I., and Geron, C.: Estimates of global terrestrial isoprene emissions using MEGAN (Model of Emissions of Gases and Aerosols from Nature), Atmos. Chem. Phys., 6, 3181-3210, doi:10.5194/acp-63181-2006, 2006.

Henderson, B. H., Pinder, R. W., Crooks, J., Cohen, R. C., Hutzell, W. T., Sarwar, G., Goliff, W. S., Stockwell, W. R., Fahr, A., Mathur, R., Carlton, A. G., and Vizuete, W.: Evaluation of simulated photochemical partitioning of oxidized nitrogen in the upper troposphere, Atmos. Chem. Phys., 11, 275-291, 
doi:10.5194/acp-11-275-2011, 2011.

Honrath, R. E., Owen, R. C., Val Martín, M., Reid, J. S., Lapina, K., Fialho, P., Dziobak, M. P., Kleissl, J., and Westphal, D. L.: Regional and hemispheric impacts of anthropogenic and biomass burning emissions on summertime $\mathrm{CO}$ and $\mathrm{O} 3$ in the North Atlantic lower free troposphere, J. Geophys. Res., 109, D24310, doi:10.1029/2004jd005147, 2004.

Horowitz, L. W., Liang, J., Gardner, G. M., and Jacob, D. J.: Export of reactive nitrogen from North America during summertime: Sensitivity to hydrocarbon chemistry, J. Geophys. Res., 103, 13451-13476, doi:10.1029/97jd03142, 1998.

Horowitz, L. W., Walters, S., Mauzerall, D. L., Emmons, L. K., Rasch, P. J., Granier, C., Tie, X., Lamarque, J.-F., Schultz, M. G., Tyndall, G. S., Orlando, J. J., and Brasseur, G. P.: A global simulation of tropospheric ozone and related tracers: Description and evaluation of MOZART, version 2, J. Geophys. Res., 108, 4784, doi:10.1029/2002jd002853, 2003.

Horowitz, L. W., Fiore, A. M., Milly, G. P., Cohen, R. C., Perring, A., Wooldridge, P. J., Hess, P. G., Emmons, L. K., and Lamarque, J.-F.: Observational constraints on the chemistry of isoprene nitrates over the eastern United States, J. Geophys. Res., 112, D12S08, doi:10.1029/2006jd007747, 2007.

Ito, A., Sillman, S., and Penner, J. E.: Global chemical transport model study of ozone response to changes in chemical kinetics and biogenic volatile organic compounds emissions due to increasing temperatures: Sensitivities to isoprene nitrate chemistry and grid resolution, J. Geophys. Res., 114, D09301, doi:10.1029/2008jd011254, 2009.

Jacob, D. J., Horowitz, L. W., Munger, J. W., Heikes, B. G., Dickerson, R. R., Artz, R. S., and Keene, W. C.: Seasonal transition from $\mathrm{NO}_{\mathrm{X}}$ - to hydrocarbon-limited conditions for ozone production over the eastern United States in September, J. Geophys. Res., 100, 9315-9324, doi:10.1029/94jd03125, 1995.

Jacob, D. J., Logan, J. A., and Murti, P. P.: Effect of rising Asian emissions on surface ozone in the United States, Geophys. Res. Lett., 26, 2175-2178, doi:10.1029/1999g1900450, 1999.

Jaffe, D., Thornton, J., Wolfe, G., Reidmiller, D., Fischer, E. V., Jacob, D. J., Cohen, R., Singh, H., Weinheimer, A., and Flocke, F.: Can we Detect an Influence over North America From Increasing Asian $\mathrm{NO}_{\mathrm{x}}$ Emissions?, EOS Trans. AGU, 88(52), Fall Meet. Suppl., Abstract A51E-04, 2007.

Johnson, C. E., Collins, W. J., Stevenson, D. S., and Derwent, R. G.: Relative roles of climate and emissions changes on future tropospheric oxidant concentrations, J. Geophys. Res., 104, 1863118645, doi:10.1029/1999jd900204, 1999.

Jonson, J. E., Stohl, A., Fiore, A. M., Hess, P., Szopa, S., Wild, O., Zeng, G., Dentener, F. J., Lupu, A., Schultz, M. G., Duncan, B. N., Sudo, K., Wind, P., Schulz, M., Marmer, E., Cuvelier, C., Keating, T., Zuber, A., Valdebenito, A., Dorokhov, V., De Backer, H., Davies, J., Chen, G. H., Johnson, B., Tarasick, D. W., Stübi, R., Newchurch, M.J., von der Gathen, P., Steinbrecht, W., and Claude, H.: A multi-model analysis of vertical ozone profiles, Atmos. Chem. Phys., 10, 5759-5783, doi:10.5194/acp10-5759-2010, 2010.

Kalnay, E., Kanamitsu, M., Kistler, R., Collins, W., Deaven, D., Gandin, L., Iredell, M., Saha, S., White, G., Woollen, J., Zhu, Y., Leetmaa, A., Reynolds, R., Chelliah, M., Ebisuzaki, W., Higgins, W., Janowiak, J., Mo, K. C., Ropelewski, C., Wang, J., Jenne, R., and Joseph, D.: The NCEP/NCAR 40-Year Reanalysis
Project, B. Am. Meteorol. Soc., 77, 437-471, doi:10.1175/15200477(1996)077<0437:TNYRP>2.0.CO;2, 1996.

Kang, D., Aneja, V. P., Mathur, R., and Ray, J. D.: Nonmethane hydrocarbons and ozone in three rural southeast United States national parks: A model sensitivity analysis and comparison to measurements, J. Geophys. Res., 108, 4604, doi:10.1029/2002jd003054, 2003.

Kleinman, L. I.: Seasonal Dependence of Boundary Layer Peroxide Concentration: The Low and High $\mathrm{NO}_{\mathrm{x}}$ Regimes, J. Geophys. Res., 96, 20721-20733, doi:10.1029/91jd02040, 1991.

Kuhn, M., Builtjes, P. J. H., Poppe, D., Simpson, D., Stockwell, W. R., Andersson-Sko“ld, Y., Baart, A., Das, M., Fiedler, F., Hov, Ø., Kirchner, F., Makar, P. A., Milford, J. B., Roemer, M. G. M., Ruhnke, R., Strand, A., Vogel, B., and Vogel, H.: Intercomparison of the gas-phase chemistry in several chemistry and transport models, Atmos. Environ., 32, 693-709, 1998.

Lathière, J., Hewitt, C. N., and Beerling, D. J.: Sensitivity of isoprene emissions from the terrestrial biosphere to 20th century changes in atmospheric $\mathrm{CO} 2$ concentration, climate, and land use, Global Biogeochem. Cy., 24, GB1004, doi:10.1029/2009gb003548, 2010.

Lelieveld, J., Butler, T. M., Crowley, J. N., Dillon, T. J., Fischer, H., Ganzeveld, L., Harder, H., Lawrence, M. G., Martinez, M., Taraborrelli, D., and Williams, J.: Atmospheric oxidation capacity sustained by a tropical forest, Nature, 452, 737-740, 2008.

Liang, J., Horowitz, L. W., Jacob, D. J., Wang, Y., Fiore, A. M., Logan, J. A., Gardner, G. M., and Munger, J. W.: Seasonal budgets of reactive nitrogen species and ozone over the United States, and export fluxes to the global atmosphere, J. Geophys. Res., 103, 13435-13450, doi:10.1029/97jd03126, 1998.

Lin, M., Holloway, T., Carmichael, G. R., and Fiore, A. M.: Quantifying pollution inflow and outflow over East Asia in spring with regional and global models, Atmos. Chem. Phys., 10, 42214239, doi:10.5194/acp-10-4221-2010, 2010.

Liu, Z., Wang, Y., Gu, D., Zhao, C., Huey, L. G., Stickel, R., Liao, J., Shao, M., Zhu, T., Zeng, L., Liu, S.-C., Chang, C.-C., Amoroso, A., and Costabile, F.: Evidence of Reactive Aromatics As a Major Source of Peroxy Acetyl Nitrate over China, Environ. Sci. Technol., 44, 7017-7022, doi:10.1021/es1007966, 2010.

McLinden, C. A., Olsen, S. C., Hannegan, B., Wild, O., Prather, M. J., and Sundet, J.: Stratospheric ozone in 3-D models: A simple chemistry and the cross-tropopause flux, J. Geophys. Res., 105, 14653-14665, doi:10.1029/2000jd900124, 2000.

Moxim, W. J., Levy II, H., and Kasibhatla, P. S.: Simulated global tropospheric PAN: Its transport and impact on $\mathrm{NO}_{\mathrm{x}}, \mathrm{J}$. Geophys. Res., 101, 12621-12638, doi:10.1029/96jd00338, 1996.

Murazaki, K. and Hess, P.: How does climate change contribute to surface ozone change over the United States?, J. Geophys. Res., 111, D05301, doi:10.1029/2005jd005873, 2006.

Pacifico, F., Harrison, S. P., Jones, C. D., and Sitch, S.: Isoprene emissions and climate, Atmos. Environ., 43, 6121-6135, 2009.

Palmer, P. I., Abbot, D. S., Fu, T.-M., Jacob, D. J., Chance, K., Kurosu, T. P., Guenther, A., Wiedinmyer, C., Stanton, J. C., Pilling, M. J., Pressley, S. N., Lamb, B., and Sumner, A. L.: Quantifying the seasonal and interannual variability of North American isoprene emissions using satellite observations of the formaldehyde column, J. Geophys. Res., 111, D12315, doi:10.1029/2005jd006689, 2006.

Paulot, F., Crounse, J. D., Kjaergaard, H. G., Kroll, J. H., Sein- 
feld, J. H., and Wennberg, P. O.: Isoprene photooxidation: new insights into the production of acids and organic nitrates, Atmos. Chem. Phys., 9, 1479-1501, doi:10.5194/acp-9-1479-2009, 2009.

Perring, A. E., Bertram, T. H., Wooldridge, P. J., Fried, A., Heikes, B. G., Dibb, J., Crounse, J. D., Wennberg, P. O., Blake, N. J., Blake, D. R., Brune, W. H., Singh, H. B., and Cohen, R. C.: Airborne observations of total RONO2: new constraints on the yield and lifetime of isoprene nitrates, Atmos. Chem. Phys., 9, 1451-1463, doi:10.5194/acp-9-1451-2009, 2009.

Pfister, G. G., Emmons, L. K., Hess, P. G., Lamarque, J. F., Orlando, J. J., Walters, S., Guenther, A., Palmer, P. I., and Lawrence, P. J.: Contribution of isoprene to chemical budgets: A model tracer study with the NCAR CTM MOZART-4, J. Geophys. Res., 113, D05308, doi:10.1029/2007jd008948, 2008.

Reidmiller, D. R., Fiore, A. M., Jaffe, D. A., Bergmann, D., Cuvelier, C., Dentener, F. J., Duncan, B. N., Folberth, G., Gauss, M., Gong, S., Hess, P., Jonson, J. E., Keating, T., Lupu, A., Marmer, E., Park, R., Schultz, M. G., Shindell, D. T., Szopa, S., Vivanco, M. G., Wild, O., and Zuber, A.: The influence of foreign vs. North American emissions on surface ozone in the US, Atmos. Chem. Phys., 9, 5027-5042, doi:10.5194/acp-9-5027-2009, 2009.

Reimann, S., Calanca, P., and Hofer, P.: The anthropogenic contribution to isoprene concentrations in a rural atmosphere, Atmos. Environ., 34, 109-115, 2000.

Ren, X., Olson, J. R., Crawford, J. H., Brune, W. H., Mao, J., Long, R. B., Chen, Z., Chen, G., Avery, M. A., Sachse, G. W., Barrick, J. D., Diskin, G. S., Huey, L. G., Fried, A., Cohen, R. C., Heikes, B., Wennberg, P. O., Singh, H. B., Blake, D. R., and Shetter, R. E.: HOx chemistry during INTEX-A 2004: Observation, model calculation, and comparison with previous studies, J. Geophys. Res., 113, D05310, doi:10.1029/2007jd009166, 2008.

Roberts, J. M., Tanner, R. L., Newman, L., Bowersox, V. C., Bottenheim, J. W., Anlauf, K. G., Brice, K. A., Parrish, D. D., Fehsenfeld, F. C., Buhr, M. P., Meagher, J. F., and Bailey, E. M.: Relationships between PAN and ozone at sites in eastern North America, J. Geophys. Res., 100, 22821-22830, doi:10.1029/95jd01221, 1995.

Roberts, J. M., Williams, J., Baumann, K., Buhr, M. P., Goldan, P. D., Holloway, J., Hübler, G., Kuster, W. C., McKeen, S. A., Ryerson, T. B., Trainer, M., Williams, E. J., Fehsenfeld, F. C., Bertman, S. B., Nouaime, G., Seaver, C., Grodzinsky, G., Rodgers, M., and Young, V. L.: Measurements of PAN, PPN, and MPAN made during the 1994 and 1995 Nashville Intensives of the Southern Oxidant Study: Implications for regional ozone production from biogenic hydrocarbons, J. Geophys. Res., 103, 22473-22490, doi:10.1029/98jd01637, 1998.

Roberts, J. M., Flocke, F., Stroud, C. A., Hereid, D., Williams, E., Fehsenfeld, F., Brune, W., Martinez, M., and Harder, H.: Ground-based measurements of peroxycarboxylic nitric anhydrides (PANs) during the 1999 Southern Oxidants Study Nashville Intensive, J. Geophys. Res., 107, 4554, doi:10.1029/2001jd000947, 2002.

Roberts, J. M., Marchewka, M., Bertman, S. B., Goldan, P., Kuster, W., de Gouw, J., Warneke, C., Williams, E., Lerner, B., Murphy, P., Apel, E., and Fehsenfeld, F. C.: Analysis of the isoprene chemistry observed during the New England Air Quality Study (NEAQS) 2002 intensive experiment, J. Geophys. Res.,
111, D23S12, doi:10.1029/2006jd007570, 2006.

Rosenstiel, T. N., Potosnak, M. J., Griffin, K. L., Fall, R., and Monson, R. K.: Increased $\mathrm{CO}_{2}$ uncouples growth from isoprene emission in an agriforest ecosystem, Nature, 421, 256-259, 2003.

Sanderson, M. G., Jones, C. D., Collins, W. J., Johnson, C. E., and Derwent, R. G.: Effect of Climate Change on Isoprene Emissions and Surface Ozone Levels, Geophys. Res. Lett., 30, 1936, doi:10.1029/2003g1017642, 2003.

Sanderson, M. G., Dentener, F. J., Fiore, A. M., Cuvelier, C., Keating, T. J., Zuber, A., Atherton, C. S., Bergmann, D. J., Diehl, T., Doherty, R. M., Duncan, B. N., Hess, P., Horowitz, L. W., Jacob, D. J., Jonson, J. E., Kaminski, J. W., Lupu, A., MacKenzie, I. A., Mancini, E., Marmer, E., Park, R., Pitari, G., Prather, M. J., Pringle, K. J., Schroeder, S., Schultz, M. G., Shindell, D. T., Szopa, S., Wild, O., and Wind, P.: A multi-model study of the hemispheric transport and deposition of oxidised nitrogen, Geophys. Res. Lett., 35, L17815, doi:10.1029/2008g1035389, 2008.

Shindell, D. T., Chin, M., Dentener, F., Doherty, R. M., Faluvegi, G., Fiore, A. M., Hess, P., Koch, D. M., MacKenzie, I. A., Sanderson, M. G., Schultz, M. G., Schulz, M., Stevenson, D. S., Teich, H., Textor, C., Wild, O., Bergmann, D. J., Bey, I., Bian, H., Cuvelier, C., Duncan, B. N., Folberth, G., Horowitz, L. W., Jonson, J., Kaminski, J. W., Marmer, E., Park, R., Pringle, K. J., Schroeder, S., Szopa, S., Takemura, T., Zeng, G., Keating, T. J., and Zuber, A.: A multi-model assessment of pollution transport to the Arctic, Atmos. Chem. Phys., 8, 5353-5372, doi:10.5194/acp-8-5353-2008, 2008.

Steiner, A. L. and Goldstein, A. H.: Biogenic volatile organic compounds, in: Volatile Organic Compounds in the Atmosphere, edited by: Koppmann, R., Blackwell Publishing, Ltd., 82-128, 2007.

TFHTAP: Task Force on Hemispheric Transport of Air Pollution 2007 Interim Report, in: Air Pollution Studies, edited by: Keating, T. J., and Zuber, A., United Nations Economic Commission for Europe, New York and Geneva, 2007.

Trainer, M., Williams, E. J., Parrish, D. D., Buhr, M. P., Allwine, E. J., Westberg, H. H., Fehsenfeld, F. C., and Liu, S. C.: Models and observations of the impact of natural hydrocarbons on rural ozone, Nature, 329, 705-707, 1987.

Val Martin, M., Honrath, R. E., Owen, R. C., and Lapina, K.: Largescale impacts of anthropogenic pollution and boreal wildfires on the nitrogen oxides over the central North Atlantic region, J. Geophys. Res., 113, D17308, doi:10.1029/2007jd009689, 2008.

van der Werf, G. R., Randerson, J. T., Giglio, L., Collatz, G. J., Kasibhatla, P. S., and Arellano Jr., A. F.: Interannual variability in global biomass burning emissions from 1997 to 2004, Atmos. Chem. Phys., 6, 3423-3441, doi:10.5194/acp-6-3423-2006, 2006.

von Kuhlmann, R., Lawrence, M. G., Pöschl, U., and Crutzen, P. J.: Sensitivities in global scale modeling of isoprene, Atmos. Chem. Phys., 4, 1-17, doi:10.5194/acp-4-1-2004, 2004.

Wang, Y., Jacob, D. J., and Logan, J. A.: Global simulation of tropospheric $\mathrm{O} 3-\mathrm{NO}_{\mathrm{x}}$-hydrocarbon chemistry 3. Origin of tropospheric ozone and effects of nonmethane hydrocarbons, J. Geophys. Res., 103, 10757-10767, doi:10.1029/98jd00156, 1998.

Warneke, C., de Gouw, J. A., Del Negro, L., Brioude, J., McKeen, S., Stark, H., Kuster, W. C., Goldan, P. D., Trainer, M., Fehsenfeld, F. C., Wiedinmyer, C., Guenther, A. B., Hansel, A., Wisthaler, A., Atlas, E., Holloway, J. S., Ryerson, T. B., Peis- 
chl, J., Huey, L. G., and Hanks, A. T. C.: Biogenic emission measurement and inventories determination of biogenic emissions in the eastern United States and Texas and comparison with biogenic emission inventories, J. Geophys. Res., 115, D00F18, doi:10.1029/2009JD012445, 2010.

Weaver, C. P., Cooter, E., Gilliam, R., Gilliland, A., Grambsch, A., Grano, D., Hemming, B., Hunt, S. W., Nolte, C., Winner, D. A., Liang, X.-Z., Zhu, J., Caughey, M., Kunkel, K., Lin, J.-T., Tao, Z., Williams, A., Wuebbles, D. J., Adams, P. J., Dawson, J. P., Amar, P., He, S., Avise, J., Chen, J., Cohen, R. C., Goldstein, A. H., Harley, R. A., Steiner, A. L., Tonse, S., Guenther, A., Lamarque, J.-F., Wiedinmyer, C., Gustafson, W. I., Leung, L. R., Hogrefe, C., Huang, H.-C., Jacob, D. J., Mickley, L. J., Wu, S., Kinney, P. L., Lamb, B., Larkin, N. K., McKenzie, D., Liao, K.-J., Manomaiphiboon, K., Russell, A. G., Tagaris, E., Lynn, B. H., Mass, C., Salathé, E., O'neill, S. M., Pandis, S. N., Racherla, P. N., Rosenzweig, C., and Woo, J.-H.: A Preliminary Synthesis of Modeled Climate Change Impacts on U.S. Regional Ozone Concentrations, B. Am. Meteorol. Soc., 90, 1843-1863, doi:10.1175/2009BAMS2568.1, 2009.

West, J. J., Naik, V., Horowitz, L. W., and Fiore, A. M.: Effect of regional precursor emission controls on long-range ozone transport - Part 1: Short-term changes in ozone air quality, Atmos. Chem. Phys., 9, 6077-6093, doi:10.5194/acp-9-6077-2009, 2009.
Wiedinmyer, C., Tie, X., Guenther, A., Neilson, R., and Granier, C.: Future Changes in Biogenic Isoprene Emissions: How Might They Affect Regional and Global Atmospheric Chemistry?, Earth Interactions, 10, 1-19, doi:10.1175/EI174.1, 2006.

Wild, O.: Modelling the global tropospheric ozone budget: exploring the variability in current models, Atmos. Chem. Phys., 7, 2643-2660, doi:10.5194/acp-7-2643-2007, 2007.

Wild, O. and Prather, M. J.: Global tropospheric ozone modeling: Quantifying errors due to grid resolution, J. Geophys. Res., 111, D11305, doi:10.1029/2005jd006605, 2006.

Wild, O., Prather, M. J., Akimoto, H., Sundet, J. K., Isaksen, I. S. A., Crawford, J. H., Davis, D. D., Avery, M. A., Kondo, Y., Sachse, G. W., and Sandholm, S. T.: Chemical transport model ozone simulations for spring 2001 over the western Pacific: Regional ozone production and its global impacts, J. Geophys. Res., 109, D15S02, doi:10.1029/2003jd004041, 2004.

Wu, S., Mickley, L. J., Jacob, D. J., Logan, J. A., Yantosca, R. M., and Rind, D.: Why are there large differences between models in global budgets of tropospheric ozone?, J. Geophys. Res., 112, D05302, doi:10.1029/2006jd007801, 2007.

Wu, S., Duncan, B. N., Jacob, D. J., Fiore, A. M., and Wild, O.: Chemical nonlinearities in relating intercontinental ozone pollution to anthropogenic emissions, Geophys. Res. Lett., 36, L05806, doi:10.1029/2008g1036607, 2009. 